DOI: https://doi.org/10.24127/ajpm.v10i1.3395

\title{
PENGEMBANGAN KARTU MAKE A MATCH BERBASIS KARAKTER ANTI KORUPSI
}

\author{
Nika Fetria Trisnawati ${ }^{1 *}$, Sundari $^{2}$ \\ ${ }^{1 *, 2}$ Pendidikan Matematika, Universitas Muhammadiyah Sorong, Indonesia \\ *Corresponding author. \\ E-mail: $\quad$ nfetristrisnawati@gmail.com ${ }^{1 *}$ \\ ndarisundari212@gmail.com ${ }^{2)}$
}

Received 18 December 2020; Received in revised form 06 March 2021; Accepted 06 April 2021

\begin{abstract}
Abstrak
Penelitian ini bertujuan untuk menghasilkan produk penelitian berupa kartu Make a Match berbasis karakter anti korupsi yang Valid, Praktis, dan Efektif. Penelitian ini merupakan penelitian pengembangan R\&D (research \& development) dengan menggunakan model Thiagarajan yang dikenal dengan 4D (define, design, develop, and disseminate), yang kemudian diadaptasi menjadi 3 prosedur pengembangan (define, design, and develop ). Dalam penelitian ini dilakukan pengembangan kartu make a match yang terintegrasi nilai-nilai karakter anti korupsi, sehingga penanaman karakter anti korupsi diintegrasikan melalui sikap dengan penerapan langkah-langkah pembelajaran make a match, dan melalui pengetahuan dengan nilai-nilai karakter anti korupsi yang diintegrasikan pada kartu make a match yang diuji cobakan pada 28 mahasiswa yang mengontrak mata kuliah analisis kompleks. Rancangan uji coba perangkat pembelajaran menggunakan one group pre test-post test. Hasil penelitian ini yaitu 1) Kartu make a match berbasis karakter anti korupsi dinyatakan valid berdasarkan hasil validasi oleh 3 orang ahli; 2) penggunaan Kartu make a match berbasis karakter anti korupsi dinyatakan praktis berdasarkan hasil analisis angket respon dari dosen yang telah menerapkan; dan 3) kartu make a match berbasis karakter anti korupsi efektif digunakan dalam mengintegrasikan karakter anti korupsi yang dilihat dari hasil analisis observasi pelaksanaan pembelajaran dan N-Gain angket karakter anti korupsi.
\end{abstract}

Kata kunci: Karakter anti korupsi kartu; make a match; media pembelajaran; pengembangan.

\begin{abstract}
This study aims to produce a research product in the form of a Make a Match card based on anticorruption characters that is valid, practical, and effective. This research is a research and development research using the Thiagarajan model known as 4D (define, design, develop, and disseminate), which is then adapted into 3 development procedures (define, design, and develop). In this study a make a match card is developed which is integrated with the values of anti-corruption characters, so that the inculcation of anti-corruption characters is integrated through attitude with the application of make a match learning steps, and through knowledge with the values of anti-corruption characters integrated into the make a match card which was tested on 28 students who contracted complex analysis courses. The trial design of the learning device used one group pre-test-post test. The results of this study were 1) the make a match card based on the anti-corruption character was declared valid based on the results of validation by 3 experts; 2) the use of the make a match card based on the anti-corruption character is stated to be practical based on the results of the response questionnaire analysis from the lecturers who have implemented it; and 3) the anti-corruption character-based make a match card is effectively used in integrating the anti-corruption character as seen from the results of the observation analysis of the implementation of learning and the N-Gain anti-corruption character questionnaire.
\end{abstract}

Keywords: Card anti-corruption character; make a match; learning media; development

This is an open access article under the Creative Commons Attribution 4.0 International License 
DOI: https://doi.org/10.24127/ajpm.v10i1.3395

\section{PENDAHULUAN}

Peguruan tinggi dalam konteks pendidikan formal menempati posisi di ujung akhir. Perguruan tinggi menjadi problem solver pada kesempatan terakhir (the last opportunity) untuk menumbuhkan potensi karakter terpuji pada diri para mahasiswa sebagai generasi penerus bangsa. Membangun negeri akan sukses apabila sukses membangun karakter mahasiswa (Kemenristek, 2017). Berdasarkan laporan tahunan Komisi Pemberantasan Korupsi (KPK) Tahun 2018 (Tim Penyususn Laporan Tahunan KPK, 2018) menyatakan tentang rangcangan untuk mewajibkan pembelajaran yang memuat nilai-nilai karakter dan budaya anti korupsi dikurikilum setiap jenjang pendidikan. Hal ini dosen sebagai pendidik di perguruan tinggi yang akan menerapkan Pendidikan Karakter Budaya anti Korupsi membutuhkan banyak referensi model-model pembelajaran yang dapat menunjang dalam pembentukan dan peningkatkan karakter anti Korupsi.

Penelitian tentang model pembelajaran yang dapat digunakan untuk mengintegrasikan pendidikan karakter telah banyak dilakukan, salah satu penelitian terkait pengintegrasian pendidikan karakter yaitu oleh Handoko dan Winarno yang menyatakan tentang model-model pembelajaran yang dapat digunakan untuk integrasi nilai-nilai karakter anti korupsi (Handoko \& Winarno, 2019). Model yang dimaksud yaitu metode Reasoning and problem solving, metode inquiri Training, Model Problem Based Instruction/Problem Based Learning, Model Konseptual, Model Investigation, pendekatan Scaffolding.

Penggunaan model pembelajaran Problem Based Learning dan Group Investigation guna mengintegrasikan karakter anti korupsi dikelas telah dilakukan oleh (N F Trisnawati \& Sundari, 2020) penelitiannya.

Selain model pembelajaran, dibutuhkan juga perangkat pembelajaran yang dapat mendukung keterlaksanaan model pembelajaran dan pengintegrasian karakter anti korupsi di kelas. Beberapa penelitian pengembangan (R\&D) yang telah dilakukan yaitu Islamic Math Comics. Media ini dikembangkan dengan mendesain gambar manual, scan, dan adobe photoshop. Islamic Math Comics merupakan komik matematika materi perbandingan bernuansa islami mengandung bimbingan karakter dan meningkatkan pemahaman matematis siswa (Basir et al., 2020).

Penelitian pengembangan lain yang telah dilakukan berkaitan dengan pengintegrasian nilai-nilai dan karakter tertentu diantaranya yaitu Pengembangan modul pembelajaran matematika pada materi statistika terintegrasi nilainilai keislaman (Ekawati et al., 2019). Pengembangan RPP dan LKS berbasis karakter kreatif (Anugraheni, 2018). Pengembangan Perangkat Pembelajaran Berbasis Subject Specific Pedagogy (SSP) Terintegrasi Pendidikan Karakter dan Revolusi Mental yang dapat meningkatkan aspek sikap tertinggi yaitu jujur, disiplin, bekerja keras, dan rasa ingin tahu (Hidayah, 2018). Pengembangan alat pembelajaran matematika yang mengintegrasikan karakterIslam melalui pendekatan kontekstual pada mata pelajaran matematika (Yuniati, 2018). Serta pengembangan perangkat pembelajaran menerapkan model pembelajaran kooperatif untuk meningkatkan ketuntasan belajar siswa dan menanamkan nilai-nilai pendidikan karakter pada mata pelajaran teknik elektronika dasar dengan mengacu 
model pengembangan Fenrich (Dyanto, 2014).

Dari pengembangan yang telah dilakukan oleh peneliti terdahulu tersebut, semuanya merupakan perangkat yang didesain hanya untuk materi atau kelas tertentu saja, tidak bisa digunakan secara luas untuk mengintegrasikan nilai-nilai karakter pada pembelajaran secara umum dikelas. Oleh karenanya dalam penelitian pengembangan ini mencoba mengembangkan sebuah perangkat yang dapat diterapkan secara umum disemua materi pelajaran dan tingkat pembelajaran.

Kartu make a match berbasis karakter anti korupsi ini didesain dengan mengintegrasikan nilai-nilai karakter anti korupsi pada pada setiap sisi kartu. Selain itu kartu make a match ini juga dilengkapi dengan kantung soal dan jawaban pada kedua sisi yang berbeda, sehingga memudahkan pengajar untuk mengganti soal dan jawaban pada kartu.

Nilai-nilai karakter anti korupsi yang dimaksud yaitu jujur, disiplin dan tanggung jawab (N F Trisnawati \& Sundari, 2020). Indikator untuk mengukur nilai kejujuran adalah tidak menyontek, dapat mengungkapkan pendapat/ mengambil sikap pada masalah yang diberikan dengan benar. Indikator untuk nilai kedisiplinan adalah mapu menyelesaikan soal pada kartu make a match tepat waktu dan mengikuti jadwal perkuliahan dan melaksanakan proses perkuliahan sesuai peraturan pembelajaran. Sedangkan indikator yang dipergunakan untuk mengukur nilai tanggung jawab peserta didik adalah menyelesaikan soal yang didapat dan membantu teman satu kelompok yang belum mendapatkan pasangan jawabannya.

Tujuan dari penelitian ini untuk menghasilkan perangkat pembelajaran yang dapat membantu pengintegrasian karakter anti korupsi di kelas yaitu kartu make a match berbasis karakter anti korupsi yang valid, praktis, dan efektif untuk meningkatkan karakter anti korupsi di kelas.

\section{METODE PENELITIAN}

Penelitian ini merupakan penelitian dan pengembangan (Research \& Development). Prosedur metode pengembangan menggunakan model Thiagarajan yang dikenal dengan 4D (define, design, develop, and disseminate). Kemudian diadaptasi menjadi 3 prosedur pengembangan (define, design, and develop).

Media pembelajaran yang dikembangkan diujikan secara terbatas pada 28 Mahasiswa kelas $G$ yang mengontrak mata kuliah analisis kompleks semester ganjil tahun 2020/2021.

Pada penelitian ini prosedur yang dilakukan hanya sampai pada tahap develop saja. Uji coba kartu make a match dilaksanakan pada pembelajaran tatap muka secara luring. Dikarenakan keterbatasan pelaksanaan pembelajaran luring karena masih berada pada masa pandemic covid-19 sehingga untuk melakukan tahap disseminate mengalami kendala.

Tahapan prosedur pada masingmasing langkah pengembangan define, design, and develop sebagai berikut: tahap pertama yaitu define, pada tahap ini dilakukan analisis terhadap peserta didik, dosen, dan materi perkuliahan melalui wawancara dan observasi. Tahap kedua adalah desaign, yang didasarkan pada hasil define yaitu dipilihnya model make a match yang dikembangkan dengan kartu make a match berbasis karakter anti korupsi. Hal yang dikembangkan yaitu: 
1. Model make a match yang dirancang dengan membagi siswa dalam kelompok kecil, kemudian siswa dalam kelompok yg telah selesai sebelum waktunya diminta untuk membantu siswa lainnya, karena nilai kelompok merupakan rata-rata dari nilai tiap individu dalam kelompok.

2. Kartu make a match yang didesain dengan 2 sisi berbeda warna untuk sisi soal dan sisi jawaban yang pada setiap sisinya dilengkapi dengan nilai-nilai karakter anti korupsi.

Tahap ketiga yaitu develop, pada tahap ini dilakukan validasi awal yang dilakukan oleh 3 Ahli yang terdiri dari 2 orang Dosen professional di Universitas Muhammadiyah Sorong dan 1 orang Guru Profesional di SMA Muhammadiyah Sorong. Perangkat yang di validasi adalah kartu make a match berbasis karakter anti korupsi dan instrumen penelitian yang digunakan dalam penelitian ini yaitu lembar observasi aktivitas dosen, lembar observasi aktivitas mahasiswa, angket respon mahasiswa, angket respon dosen, dan angket karakter anti korupsi. Hasil validasi dikategorikan berdasarkan kriteria validitas instrument seperti pada Tabel 1. Setelah dilakukan proses validasi dan dinyatakan valid dengan rata-rata persentase $>75 \%$, kemudian dilakukan revisi kecil sesuai dengan arahan dari 3 validator ahli.

Tabel 1. Interpretasi penilaian validitas instrumen

\begin{tabular}{cc}
\hline Persentase (\%) & Kriteria Validasi \\
\hline $75<\% \leq 100$ & Valid \\
$56<\% \leq 75$ & Cukup Valid \\
$39<\% \leq 56$ & Kurang Valid \\
$\% \leq 39$ & Tidak Valid \\
\hline & (Suprianto et al., 2020)
\end{tabular}

Tahap develop selanjutnya adalah uji coba perangkat. Proses uji coba perangkat menggunakan one group pre test - post test yang dilakukan pada 28 mahasiswa kelas $\mathrm{G}$ yang mengontrak mata kuliah analisis kompleks semester ganjil tahun 2020/2021. Pada tahapan ini, mahasiswa diberikan angket karakter anti korupsi sebelum dan sesudah dilakukannya uji coba guna melihat peningkatan karakter anti korupsi dari mahasiswa dan dilakukan observasi selama uji coba serta penyebaran angket respon kepada dosen dan mahasiswa.

Data kepraktisan diperoleh dari hasil analisis observasi keterlaksanaan pembelajaran, angket respon dosen, dan angket respon mahasiswa. Hasil analisis terhadap observasi keterlaksanaan pembelajaran kemudian dikategorikan berdasarkan kriteria tingkat keterlaksanaan pembelajaran seperti pada Tabel 2. Sedangkan untuk hasil dari angket respon dosen maupun mahasiswa dikategorikan berdasarkan kriteria penilaian kepraktisan instrumen seperti pada Tabel 3 .

Tabel 2. Kriteria tingkat keterlaksanaan pembelajaran (TKP)

\begin{tabular}{cc}
\hline TKP & Kriteria \\
\hline $3,5<\mathrm{TKP} \leq 4$ & Sangat Baik \\
$2,5<\mathrm{TKP} \leq 3,5$ & Baik \\
$1,5<\mathrm{TKP} \leq 2,5$ & Tidak Baik \\
$\mathrm{TKP} \leq 1,5$ & Sangat Tidak Baik \\
\hline
\end{tabular}

Tabel 3. Interpretasi kriteria penilaian kepraktisan instrumen

\begin{tabular}{cc}
\hline Persentase (\%) & Tingkat Kepraktisan \\
\hline $84<\% \leq 100$ & Sangat praktis \\
$69<\% \leq 84$ & Praktis \\
$54<\% \leq 69$ & Cukup Praktis \\
$49<\% \leq 54$ & Kurang Praktis \\
$\% \leq 49$ & Tidak Praktis \\
\hline \multicolumn{2}{c}{ (Suprianto et al., 2020) } \\
Data keefektifan diperoleh dari \\
hasil analisis observasi aktivitas
\end{tabular}


mahasiswa dan hasil analisis pre testpost test angket karakter anti korupsi mahasiswa. Hasil observasi digunakan untuk mendeskripsikan sikap mahasiswa dalam proses perkuliahan yang menunjukkan karakter inti (jujur, disiplin, dan tanggung jawab). Sedangkan data pre test - post test angket karakter anti korupsi dianalisis guna mengetahui peningkatan karakter anti korupsi mahasiswa yang dianalisis menggunakan indeks $\mathrm{N}$-gain dan kemudian dikategorikan berdasarkan Tabel 4.

Tabel 4. Kriteria indeks $N$-gain

\begin{tabular}{cc}
\hline Indeks $\boldsymbol{N}$-Gain & Kriteria \\
\hline $\mathrm{n} \geq 0,7$ & Tinggi \\
$0,3<<0,7$ & Sedang \\
$\mathrm{n} \leq 0,3$ & Rendah \\
\hline
\end{tabular}

(Suprianto et al., 2020)

\section{HASIL DAN PEMBAHASAN}

Penelitian ini menghasilkan produk berupa kartu make a match. Kartu make a match ini dikembangkan menjadi sebuah produk yang dilengkapi dengan nilai-nilai karakter anti korupsi. Kartu ini dirancang agar dapat digunakan secara umum oleh seluruh pendidik serta mudah diterapkan dalam pembelajaran.

Prosedur penelitian pengembangan ini mengacu pada model pengembangan Thiagarajan yang dikenal dengan 4D (define, design, develop, and disseminate). Namun pada penelitian ini dibatasi hanya sampai tahap develop saja. Berikut pemaparan prosedur penelitian pada setiap tahapan.

\section{Define (Pendefinisian)}

Langkah awal yang dilakukan dalam melakukan penelitian ini adalah pendefinisian, dimana dalam proses pendefinisian ini dilakukan analisis terhadap peserta didik, dosen, dan materi perkuliahan melalui wawancara dan observasi. Berikut hasil observasi dan wawancara adapun hasil dari pendefinisian sebagai berikut:

a. Berdasarkan hasil observasi, terlihat bahwa mahasiswa cenderung pasif. Mahasiswa hanya menerima saja apa yang disampaikna dosen. Saat dosen memberikan stimulus untuk direspon, sebagian besar mahasiswa diam dan tidak merespon.

b. Mahasiswa kurang bertanggung jawab saat diberikan tugas. Ada yang tidak menyelesaikan tugas yang diberikan oleh dosen.

c. Mahasiswa belum menyadari pentingnya kejujuran, mereka menganggap bahwa menyontek itu hal biasa. Hal ini terlihat dari banyak mahasiswa yang jika diberikan tugas, lambat merespon atau mengerjakannya. Mereka cenderung mengharapkan untuk mendapatkan contekan jawaban dari temannya yang mengerjakan

d. Kedisiplinan mahasiswa rendah, hal ini nampak pada banyaknya mahasiswa yang terlambat memasuki ruang kelas serta berdasarkan hasil wawancara terhadap dosen yang menyatakan mahasiswa yang terlambat dalam mengumpulkan tugas.

Hasil dari pendefinisian inilah yang kemudian menjadi dasar untuk menentukan perumusan masalah dari penelitian pengembangan ini.

\section{Design (Perancangan)}

Tahap perancangan dilakukan berdasarkan hasil pendefinisian. Dari hasil pendefinisian terlihat bahwa motivasi mahasiswa masih kurang. Hal ini adalah salah satu faktor yang membuat mahasiswa terlihat pasif dalam pembelajaran, Mahasiswa kurang bertanggung jawab, serta tingkat 
kejujuran dan kedisiplinan masih rendah.

Berdasarkan beberapa masalah tersebut, maka dipilih sebuah model pembelajaran yang dapat membuat mahasiswa ikut berperan aktif dalam kelas, yaitu model pembelajaran kooperatif tipe make a match dengan mengembangkan kartu make a macth yang diintegrasikan nilai-nilai inti dari pendidikan karakter, yaitu jujur, disiplin dan tanggung jawab.

Pembelajaran kooperatif merupakan model pembelajaran yang baik untuk diterapkan di kelas. Hal ini karena model pembelajaran kooperatif dapat membuat peserta didik berperan aktif dalam kelas (Arsyad, 2019); (Setyo \& Mulyono, 2019) \& (Nika Fetria Trisnawati, 2019). Model pembelajaran kooperatif juga mampu untuk meningkatkan hasil belajar peserta didik karena peserta didik melakukan pembelajaran secara aktif (Fathurrahman, 2016) \& (Nika Fetria Trisnawati, 2017). Selain berperan aktif, model pembelajaran kooperatif dapat menumbuhkan nilai-nilai sikap karakter pada diri peserta didik melalui penerapan langkah-langkah model pembelajarannya ( $\mathrm{N} F$ Trisnawati \& Sundari, 2020).

Setelah memperoleh gambaran pembelajaran yang akan digunakan, maka selanjutnya adalah mendesain perangkat yang akan digunakan dalam pembelajaran. Pada tahap ini, desain yang dikembangkan perangkat pembelajaran yaitu kartu make a match dan model pembelajaran make a match. Berikut disajikan rincian perancangan yang dilakukan dalam penelitian ini.

a. Desain model Pembelajaran Make a Match.

Pengembangan dapat dilakukan dengan cara menambahkan langkah pada model pembelajaran ataupun merubahnya agar menjadi lebih efektif terhadap tujuan pembelajaran (Suprianto et al., 2016), Pengembangan design yang dilakukan mengadaptasi langkah-langkah pembelajaran dari make a match. Pengembangan design yang dilakukan dapat dilihat pada Tabel 5 .

Berdasarkan Tabel 5. Diketahui bahwa terjadi pengembangan design di beberapa langkah Make a Match, yaitu:

(1) pada langkah 1, dilakukan pengembangan pada kartu yang tadinya 1 kartu untuk kartu soal atau jawaban, kemudian dikembangkan menjadi 1 kartu menjadi kartu soal dan jawaban pada kedua sisi yang berbeda. Hal ini bertujuan agar semua siswa berperan aktif mengerjakan soal yang kemudian mencari jawabannya pada sisi kartu jawaban dari teman dalam kelompoknya. (2) pada langkah 2 dilakukan pengembangan model pengelompokan menjadi kelompok kecil yang terdiri dari 4-5 orang siswa agar proses make a match lebih terarah mudah dikontrol. (3) pada langkah 3, setelah menyelesaikan soal, siswa akan mencari kartu jawaban yang ada di sisi kartu jawaban teman dalam kelompoknya. (4) pada langkah 4, peneliti mengembangkan sistem penskoran, yaitu bagi siswa yg telah menyelesaikan saol dan berhasil menemukan pasangannya diberi poin 1 , siswa yang dapat membantu temannya menemukan jawabannya diberi poin 1 yang dimaksudkan agar siswa termotivasi dan tumbuh sikap peduli terhadap temannya, kemudian nilai kelompok dihitung berdasarkan ratarata skor perolehan dari setiap anggota kelompok bertujuan agar siswa terbangun sikap tanggung jawabnya untuk menjadi bagian dalam kelompok, 
DOI: https://doi.org/10.24127/ajpm.v10i1.3395

dan berlomba-lomba untuk membantu teman dalam kelompoknya menyelesaikan jawaban. (5) perubahan desain terakhir pada langkah 5, yaitu menukar paket kartu dengan kelompok lain, karena paket kartu soal make a match untuk setiap kelompok berbeda namun dengan tingkat kesukaran yang sama, sehingga siswa bisa mengulangi proses make a match beberapa kali dalam pembelajaran selama waktu masih mencukupi.

Tabel 5. Perbandingan langkah langkah make a match setelah dikembangkan.

\begin{tabular}{|c|c|c|}
\hline \multirow{2}{*}{ No- } & \multicolumn{2}{|c|}{ Langkah-langkah make a match } \\
\hline & Aqib (2013) & Pengembangan \\
\hline 1 & $\begin{array}{l}\text { Guru menyiapkan beberapa kartu yang berisi } \\
\text { beberapa konsep atau topik yang cocok } \\
\text { untuk sesi review (terdiri dari kartu soal dan } \\
\text { kartu jawaban pada kartu yang berbeda) }\end{array}$ & $\begin{array}{l}\text { Guru menyiapkan beberapa kartu yang berisi } \\
\text { beberapa konsep atau topik yang cocok untuk sesi } \\
\text { review (satu kartu dengan satu sisi berupa kartu } \\
\text { soal dan sisi sebaliknya berupa kartu jawaban) }\end{array}$ \\
\hline & $\begin{array}{l}\text { siswa dalam kelas dikelompokkan menjadi } 2 \\
\text { kelompok yang terdiri dari kelompok Soal } \\
\text { dan Kelompok Jawaban }\end{array}$ & $\begin{array}{l}\text { Siswa dibagi kedalam kelompok kecil yang terdiri } \\
\text { dari } 4-5 \text { orang siswa. }\end{array}$ \\
\hline 2 & $\begin{array}{l}\text { Setiap siswa mendapat satu kartu dan } \\
\text { memikirkan jawaban atau soal dari kartu } \\
\text { yang dipegang }\end{array}$ & $\begin{array}{l}\text { Setiap kelompok diberikan paket soal, setiap siswa } \\
\text { dalam satu kelompok mendapat satu kartu dan } \\
\text { memikirkan jawaban dari kartu yang dipegang }\end{array}$ \\
\hline & Siswa mencari pasangan yang mempunyai & Siswa mencari yang kartu yang cocok dengan \\
\hline 3 & $\begin{array}{l}\text { kartu yang cocok dengan kartunya (kartu } \\
\text { soal atau kartu jawaban). }\end{array}$ & $\begin{array}{l}\text { kartunya (sisi kartu jawaban yang ada pada teman } \\
\text { sekelompok). }\end{array}$ \\
\hline 4 & $\begin{array}{l}\text { Siswa yang dapat mencocokan kartu nya } \\
\text { sebelum batas waktu diberi poin }\end{array}$ & $\begin{array}{l}\text { Siswa yang dapat mencocokan kartunya sebelum } \\
\text { batas waktu diberi poin, siswa yang dapat } \\
\text { membantu teman kelompoknya menyelesaikan } \\
\text { jawaban diberi poin, skor kelompok merupakan } \\
\text { rata-rata dari skor tiap anggota kelompok. }\end{array}$ \\
\hline 5 & $\begin{array}{l}\text { Setelah satu babak kartu dikocok lagi agar } \\
\text { tiap siswa mendapat kartu yang berbeda dari } \\
\text { sebelumnya, demikian seterusnya }\end{array}$ & $\begin{array}{l}\text { Setelah satu babak, paket kartu ditukar dengan } \\
\text { paket kartu kelompok lain agar tiap siswa } \\
\text { mendapat kartu yang berbeda dari sebelumnya, } \\
\text { demikian seterusnya }\end{array}$ \\
\hline 6 & Kesimpulan & Kesimpulan \\
\hline
\end{tabular}

b. Desain Kartu Make a Match berbasis Karakter Anti Korupsi

Pengembangan desain dilakukan pada kartu yang akan digunakan dalam proses pembelajaran make a match. Kartu yang awalnya hanya kertas yang bertuliskan soal atau jawaban, kemudian didesign agar praktis dan ekonomis. Peneliti mendesign kartu agar dapat digunakan terus menerus pada semua materi dan mata pelajaran.

Kartu didesign menjadi 2 sisi dengan warna berbeda, sisi berwarna putih sebagai sisi soal dan sisi berwarna merah muda sebagai sisi jawaban. Untuk memudahkan penggantian soal, setiap sisi pada kartu dilengkapi dengan kantung soal dan jawaban yang terbuat dari plastik transparan. Pengajar hanya perlu menyiapkan potongan kertas yang berisi soal dan jawaban yang kemudian dimasukkan ke dalam kantung soal maupun jawaban.

Selain mendesign bentuknya agar praktis dan ekonomis, peneliti juga mengembangkan design kartu agar lebih menarik sekaligus mampu memberikan pengetahuan tentang nilai-nilai karakter. Pentingnya mengintegrasikan nilai-nilai karakter dalam setiap pembelajaran (Pratama et al., 2019) \& (Khoiriyah \& Rizki, 2017) sehingga pada setiap kartu 
di kedua sisinya dilengkapi dengan ganbar dan tulisan-tulisan yang mengandung nilai-nilai karakter anti korupsi atau nilai-nilai inti pendidikan karakter yaitu Jujur, disiplin, dan tanggung jawab (N F Trisnawati \& Sundari, 2020). Contoh desain kartu make a match berbasis karakter anti korupsi pada kedua sisi, yaitu sisi soal berwarna putih dan sisi jawaban yang berwarna merah muda yang telah dilengkapi dengan kantung soal dan jawaban dapat dilihat pada Gambar 1.
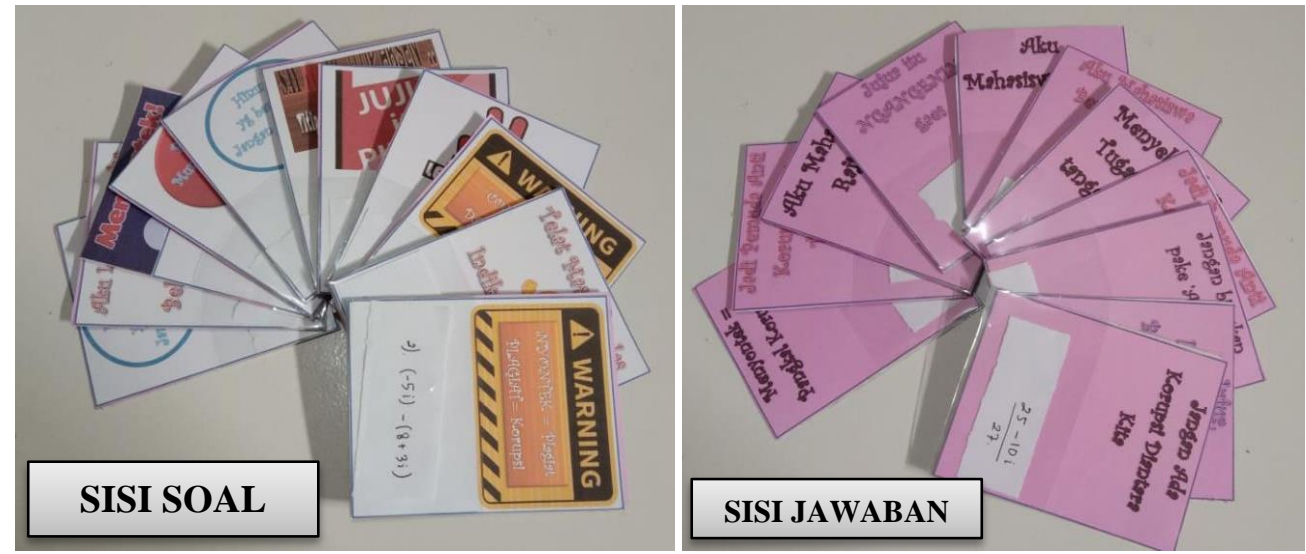

Gambar 1. Gambar kartu make a match berbasis karakter anti korupsi

Selain membuat desain dari Model pembelajaran dan perangkat pembelajaran yang akan diterapkan dalam kelas, juga disiapkan instrumen penelitian yang digunakan untuk mengumpulkan data hasil penelitian. Instrumen penelitian yang disiapkan adalah (1) Lembar Observasi sikap mahasiswa selama pembelajaran; (2) lembar observasi keterlaksanaan pembelajaran; (3) Angket Respon Dosen; (4) Angket respon Mahasiswa; (5) Satuan Acara Pembelajaran (SAP) dan (6) angket Karakter anti Korupsi Mahasiswa yang diberikan di awal sebelum uji coba dan setelah uji coba.

Lembar Observasi digunakan untuk melihat perubahan sikap Mahasiswa selama proses pembelajaran. Sikap yang dimaksud adalah jujur, disiplin dan tanggung jawab. Indikator untuk mengukur nilai kejujuran adalah tidak menyontek, dapat mengungkapkan pendapat/mengambil sikap pada masalah yang diberikan dengan benar. Indikator untuk nilai kedisiplinan adalah mapu menyelesaikan soal pada kartu make a match tepat waktu dan mengikuti jadwal perkuliahan dan melaksanakan proses perkuliahan sesuai peraturan pembelajaran. Sedangkan indikator yang dipergunakan untuk mengukur nilai tanggung jawab peserta didik adalah menyelesaikan soal yang didapat dan membantu teman satu kelompok yang belum mendapatkan pasangan jawabannya.

Lembar Observasi keterlaksanaan pembelajaran didesain agar dapat mengukur keterlaksanaan dari langkah-langkah pembelajaran make a match. Data ini digunakan sebagai salah satu indikator dari kepraktisan dalam melakukan proses pembelajaran dengan make a match dan kartu karakter anti korupsi yang dikembangkan. Selain dengan 
observasi, kepraktisan perangkat yang dikembangkan juga dilihat dari hasil angket respon dosen dan angket respon mahasiswa.

Angket karakter anti korupsi didesain agar dapat mengukur perubahan pengetahuan dan motivasi mahasiswa dalam menerapkan nilainilai karakter anti korupsi. angket yang digunakan merupakan angket tertutup yang menggunakan pilihan jawaban 4 pilihan jawaban, yaitu Selalu, Sering, Kadang-kadang, dan tidak pernah. Angket terdiri dari 50 pernyataan, dengan 30 pernyataan positif dan 20 pernyataan negatif.

\section{Develop (Pengembangan)}

Setelah semua perangkat dan instrumen telah selesai dirancang, berikutnya adalah tahap Develop. Dalam tahapan develop ini hal-hal yang dilakukan adalah validasi seluruh perangkat yang akan digunakan, Uji coba dari pembelajaran dan kartu karakter anti korupsi yang telah didesign, dan Analisis dari data hasil uji coba pembelajaran make a match dan kartu make a match berbasis karanter anti korupsi.

\section{a. Validasi}

Seluruh perangkat dan instrumen dinilai kelayakannya oleh 3 Ahli yang terdiri dari 2 orang dosen professional dan 1 orang guru profesional. Dua orang dosen profesional yang bertindak sebagai ahli adalah dosen profesional di Universitas Muhammadiyah Sorong yaitu Arie Anang Setyo, S.Pd., M.Pd dan Muhammad Fathurrahman, S.Pd., M.Pd. Sedangkan untuk 1 guru profesional, yaitu guru profesional di SMA Muhammadiyah Sorong yaitu Dra. H. Nurfin Moha.

Beberapa masukan untuk perbaikan dari para validator yaitu (1) lembar observasi mahasiswa lebih diperjelas lagi untuk indicator penilaiannya, yaitu gunakan 1 kata kerja per indikator; (2) angket respon mahasiswa yang digunakan untuk memperoleh data kepraktisan sebaiknya lebih difokuskan pada pernyataan untuk data kepraktisan; (3) Angket Karakter anti korupsi disesuaikan perbandingannya untuk pernyataan negative dan positif, serta perbandingan penrnyataan untuk sikap jujur, disiplin, dan tanggung jawab; (4) Kartu Karakter Anti Korupsi sebaiknya pilih warna yang lebih terang, sehingga gambar dan tulisannya lebih jelas dan menarik. Untuk rata-rata persentase hasil validasi dapat dilihat pada Tabel 6.

Tabel 6. Hasil Validasi

\begin{tabular}{lc}
\hline Perangkat Penelitian & $\begin{array}{c}\text { Hasil } \\
\text { Validasi } \\
(\mathbf{\%})\end{array}$ \\
\hline Lembar Observasi Dosen & 90 \\
Lembar Observasi & 92,5 \\
Mahasiswa & 85 \\
Angket Respon Mahasiswa & 90 \\
Angket Karakter Anti & 95 \\
Korupsi & 97,5 \\
Angket Respon Dosen & 92,5 \\
SAP & LKPD dalam bentuk Kartu \\
Karakter Anti Korupsi & \multicolumn{1}{c}{ Rata-Rata } \\
\hline
\end{tabular}

Berdasarkan hasil validasi yang disajikan pada Tabel 6, dapat dilihat bahwa rata-rata persentase hasil validasi dari 3 orang ahli adalah 90,4 yang berdasarkan Tabel 1 berada pada kategori valid.

b. Uji Coba

Media pembelajaran yang dikembangkan diujikan secara terbatas pada 28 Mahasiswa kelas $G$ yang mengontrak mata kuliah analisis 
kompleks semester ganjil tahun 2020/2021. Proses uji coba perangkat menggunakan one group pre test-post test yang dilakukan selama 6 kali pertemuan, yaitu 2 kali pengisian angket karakter anti yang hasilnya analisisnya dapat dilihat pada Tabel 10 dan 4 kali proses pembelajaran.

Pada hari pertama, dilakukan pembagian angket karakter anti korupsi pada Mahasiswa. Kemudian dilanjutkan dengan menyampaikan rencana pembelajaran yang akan dilaksanakan pada pertemuan berikutnya dengan menggunakan model make a match. Mahasiswa didberi penjelasan tentang make a match, langkah-langkah pembelajarannya, dan kartu make a match berbasis karakter anti korupsi yang akan digunakan dalam pembelajaran.

Pada hari ke-2, 3, 4, dan 5, peneliti melaksanakan pembelajaran dengan model pembelajaran kooperatif tipe make a match, disini dosen memfasilitasi perkuliahan dengan model make a match berdasarkan SAP yang telah disiapkan. Pada hari ke-6 diberikan post test berupa angket karakter anti korupsi. angket ini digunakan untuk memperoleh data perubahan sikap dan pengetahuan yang berkaitan dengan nilai-nilai karakter anti korupsi.

Data yang diperoleh dari proses uji coba produk adalah data keterlaksanaan pembelajaran, data hasil angket respon dosen, dan data angket respon mahasiswa yang akan digunakan untuk memperoleh data kepraktisan dari produk yang dikembangkan. Data observasi sikap mahasiswa dan data hasil angket karakter anti korupsi mahasiswa akan digunakan untuk memperoleh data keefektifan terhadap karakter anti korupsi dari produk yang dikembangkan.

\section{c. Analisis}

Setelah melakukan uji coba produk yang dikembangkan dan telah memperoleh data hasil penelitian yang dibutuhkan, maka berikutnya data-data tersebut akan dianalisis guna memperoleh data kepraktisan dan keefektifan. Data kepraktisan diperoleh dari analisis data hasil keterlaksanaan pembelajaran, data hasil angket respon dosen, dan data angket respon mahasiswa. Sedangkan data keefektifan diperoleh dari hasil analisis data observasi sikap mahasiswa dan data hasil angket karakter anti korupsi mahasiswa.

1) Praktis

Data kepraktisan yang pertama adalah data keterlaksanaan pembelajaran. Data keterlaksanaan pembelajaran selama 4 kali tatap muka dapat dilihat pada Tabel 7.

Tabel 7. Data keterlaksanaan pembelajaran

\begin{tabular}{|c|c|}
\hline Pertemuan & Total Skor \\
\hline $\mathrm{I}$ & 3,6 \\
\hline II & 3,67 \\
\hline III & 3,74 \\
\hline IV & 3,8 \\
\hline Rata-Rata & 3,7 \\
\hline Persentase & 92,56 \\
\hline
\end{tabular}

kriteria keterlaksanaan pembelajaran, maka dapat disimpulkan bahwa keterlaksanaan pembelajaran berada pada kategori sangat baik, yaitu dengan rata-rata keterlaksanaan 3,7 (Tabel 7). Hal ini dapat diinterpretasikan bahwa dosen dapat dengan baik memahami dan melaksanakan perkuliahan dengan model make a match berbasis karakter anti korupsi.

Setelah selesai uji coba selama 4 kali pertemuan, mahasiswa mengisi angket yang berisi tanggapan 
mahasiswa tentang model pembelajaran yang telah dilakukan. Hasil angket respon mahasiswa dapat dilihat pada Tabel 8.

Tabel. 8 Respon mahasiswa terhadap pembelajaran make a match berbasis karakter anti korupsi

\begin{tabular}{lc}
\hline \multicolumn{1}{c}{ Indikator } & $\begin{array}{c}\text { Total } \\
\text { Skor }\end{array}$ \\
\hline Menarik perhatian Mahasiswa & 102 \\
Memberikan Motivasi & 96 \\
Kejelasan Materi & 89 \\
Kemampuan Mengelola Kelas & 98 \\
Penggunaan Waktu secara & 90 \\
efisien & 95 \\
Penekanan nilai Karakter & 97 \\
Menarik Kesimpulan & 667 \\
Jumlah & $85,08 \%$ \\
\hline Persentase & \\
\hline
\end{tabular}

Berdasarkan Tabel 8 dapat diketahui bahwa respon mahasiswa terhadap pembelajaran dengan model make a match yang dikembangkan dan kartu karakter anti korupsi memperoleh penilaian sangat praktis. Hal ini diperkuat dengan hasil tanggapan dosen terhadap model make a match dan kartu karakter anti korupsi yang telah diterapkan pada mata kuliahnya. Hasil dari respon yang diberikan dosen melalui angket respon dosen dapat dilihat pada Tabel 9.

Tabel 9. Tanggapan dosen terhadap model make a match berbasis karakter anti korupsi

\begin{tabular}{lcc}
\hline \multicolumn{1}{c}{ Aspek } & Skor Total & Persentase \\
\hline Petunjuk & 8 & 100 \\
Cakupan & 9 & 90 \\
Penggunaan & 22 & 88 \\
Bahasa & 7 & 87,5 \\
\hline Rata-Rata & 11,5 & 91,38 \\
\hline
\end{tabular}

Berdasarkan hasil analisis keterlaksanaan pembelajaran yang berada pada kategori terlaksana sangat baik, rata-rata respon mahasiswa yang memberikan tanggapan sangat praktis, dan tanggapan guru terhadap model yang dikembangkan dan kartu make a match berbasis karakter anti korupsi dengan penilaian sangat praktis, maka dapat disimpulkan bahwa model make a match dengan kartu karakter anti korupsi sangat praktis untuk diterapkan dalam proses pembelajaran dikelas.

\section{2) Efektif}

Data keefektifan dari model make a match yang dikembangkan dan kartu karakter anti korupsi didapat dari hasil analisis observasi sikap siswa selama pembelajaran dan indeks $\mathrm{N}$-gain angket karakter anti korupsi. Lembar observasi diisi selama 4 kali uji coba. Sikap yang diobservasi sebanyak 6 indikator yang mewakili 3 karakter inti, yaitu jujur, disiplin, dan tanggung jawab.

Keenam indikator tesebut yaitu Indikator untuk mengukur nilai kejujuran (1) tidak menyontek, (2) dapat mengungkapkan pendapat/ mengambil sikap pada masalah yang diberikan dengan benar. Indikator untuk nilai kedisiplinan (3) mampu menyelesaikan soal pada kartu make a match tepat waktu dan (4) mengikuti jadwal perkuliahan dan melaksanakan proses perkuliahan sesuai peraturan pembelajaran. Sedangkan indikator yang dipergunakan untuk mengukur nilai tanggung jawab peserta didik adalah (5) menyelesaikan soal yang didapat dan (6) membantu teman satu kelompok yang belum mendapatkan pasangan jawabannya. Hasil Observasi sikap mahasiswa disajikan pada Tabel 10 . 
DOI: https://doi.org/10.24127/ajpm.v10i1.3395

Tabel 10. Hasil observasi sikap

\begin{tabular}{crrrr}
\hline Indikator & \multicolumn{4}{c}{ Pertemuan (\%) } \\
\cline { 2 - 5 } Sikap \\
Mahasiswa & \multicolumn{1}{c}{ I } & \multicolumn{1}{c}{ II } & \multicolumn{1}{c}{ III } & IV \\
\hline 1 & 64,3 & 71,5 & 89,3 & 89,3 \\
2 & 53,5 & 64,3 & 75 & 78,5 \\
3 & 67,8 & 78,5 & 89,3 & 89,3 \\
4 & 60,8 & 89,3 & 92,8 & 92,8 \\
5 & 50 & 75 & 82,3 & 96,5 \\
6 & 14,3 & 25 & 32,3 & 39,3 \\
\hline
\end{tabular}

Tabel 10 menunjukkan bahwa terjadi perubahan sikap pada 6 indikator yang diamati selama 4 kali pertemuan. Disini terlihat bahwa mahasiswa aktif dalam mengikuti pembelajaran dikelas. Keaktifan peserta didik sangat berpengaruh terhadap tercapainya tujuan pembelajaran (Waluyo et al., 2020); (Heriyadi \& Prahmana, 2020).

Sikap kejujuran dari mahasiswa selama perkuliahan dapat dilihat dari indikator 1 dan 2. Pada awal pertemuan, banyak mahasiswa yang hanya diam saja dan menunggu teman yang mengerjakan tanpa berusaha terlebih dahulu, hal ini mengalami penurunan pada setiap pertemuan, sehingga diakhir pertemuan terlihat bahwa mahasiswa percaya diri dan berusaha mengerjakan tugas.

Sikap disiplin dilihat dari indikator 3 dan 4 , dengan adanya metode make a match terlihat mahasiswa berlomba-lomba untuk segera menyelesaikan soal yang diberikan. Tingkat kehadiran mahasiswa juga meningkat.

Sikap tanggung jawab dilihat dari indikator 5 dan 6 . Yang awalnya siswa cenderung tidak menyelesaikan soal dan lebih memilih menyerah, kemudian diakhir pertemuan terlihat bahwa mahasiswa lebih antusias dan bertanggung jawab menyelesaikan soal, serta setiap mahasiswa yang telah mendapatkan pasangan jawabannya akan membantu temannya yang belum menemukan pasangan jawaban.

Dengan demikian, dapat disimpulkan bahwa penerapan langkah-langkah model make a match berbasis kartu karakter anti korupsi dalam pembelajaran dikelas efektif meningkatkan sikap karakter anti korupsi mahasiswa.

Berikutnya pada Tabel 11 dipaparkan tentang indeks N-Gain dari angket karakter anti korupsi.

Tabel 11. N-Gain karakter anti korupsi

\begin{tabular}{clc}
\hline No & Aspek yang diamati & Nilai \\
\hline 1 & Jumlah Siswa & 28 \\
& Indeks Gain & 0,34 \\
2 & $\begin{array}{l}\text { Terendah } \\
\text { Indeks Gain }\end{array}$ & 0,7 \\
3 & Tertinggi & $\mathbf{0 , 6 5}$ \\
\hline & Rata-Rata N-Gain &
\end{tabular}

Berdasarkan Tabel 11 diketahui bahwa perubahan karakter mahasiswa setelah dilakukan pembelajaran dengan model make a match dan kartu karakter anti korupsi mengalami peningkatan dengan rata-rata indeks berada pada kategori sedang.

Dari hasil observasi sikap siswa selama pembelajaran dan hasil angket karakter anti korupsi mahasiswa, maka diperoleh penilaian terhadap model make a match dan kartu karakter anti korupsi yang efektif meningkatkan karakter anti korupsi mahasiswa yaitu jujur, disiplin dan tanggung jawab. Hal ini sesuai dengan hasil penelitian yang sudah pernah dilakukan, diantaranya: (Basir et al., 2020); (Ekawati et al., 2019); (Anugraheni, 2018); (Hidayah, 2018); (Yuniati, 2018); dan (Dyanto, 2014) bahwa pengembangan perangkat pembelajaran yang diintegrasikan dengan nilai-nilai karakter efektif dalam 
menumbuhkan dan meningkatkan karakter peserta didik.

Kelebihan dari pengembangan model pembelajaran dan perangkat pembelajaran yang dilakukan adalah model dan perangkat yang dikembangkan tidak terikat oleh materi tertentu, sehingga model make a match yang dikembangkan dan juga kartu make a match berbasis karakter anti korupsi dapat digunakan secara umum pada semua materi dan jenjang pendidikan. Sedangkan kelemahan dari Kartu Make a Match yang dikembangkan ini hanya dapat diterapkan pada pembelajaran offline.

Dalam penelitian ini dihasilkan kartu make a match yang dikembangkan dengan mengintegrasikan nilai-nilai karakter anti korupsi. desain dari kartu make a match ini memungkinkan untuk dapat digunakan pada semua mata pelajaran. Dengan adanya kartu make a match ini dapat membantu pengajar dalam mengintegrasikan karakter anti korupsi pada pembelajaran dikelas dengan mudah. Kartu make a match ini memberikan kepraktisan kepada pengajar untuk menggunakan pembelajaran yang menarik dengan bantuan alat peraga dan menjadi salah satu alat peraga yang dapat memudahkan dan melancar-kan pembelajaran dan penerapan nilai-nilai karakter di dalam kelas.

\section{KESIMPULAN DAN SARAN}

Penelitian Pengembangan ini menghasilkan kartu Make a Match berbasis karakter anti korupsi yang valid, sangat praktis, dan efektif. Selain mengembangkan kartu make a match berbasis karakter anti korupsi, pada penelitian ini juga dilakukan pengembangan model pembelajaran make a match guna memaksimalkan penerapan kartu make a match dalam pembelajaran. Penngembangannya berupa penyesuaian beberapa Langkah pembelajaran dari Langkahlangkah pembelajaran make a match yang telah ada.

Untuk pengembangan lebih lanjut akan dilakukan tahap disseminate, produk hasil pengembangan ini akan dijadikan perangkat pembelajaran yang disosialisasikan pada program pengabdian kepada masyarakat, yaitu berupa workshop penerapan model make a match dan penggunaan kartu make a match berbasis karakter anti korupsi pada guru-guru di Papua Barat. Pengembangan produk ataupun model pembelajaran yang berkaitan dengan Pendidikan karakter masih sangat dibutuhkan, mengingat kurangnya referensi pengajar dalam mengintegrasikan Pendidikan karakter di kelas.

\section{DAFTAR PUSTAKA}

Anugraheni, I. (2018). Pengembangan Perangkat Pembelajaran Matematika Berbasis Pendidikan Karakter Kreatif Di Sekolah Dasar. Refleksi Edukatika: Jurnal Ilmiah Kependidikan, 8(2). https://doi.org/10.24176/re.v8i2.2 351

Arsyad, R. Bin. (2019). Meningkatkan Hasil Belajar Matematika Dengan Menggunakan Model Cooperative Learning Dan Teknik Napier Pada Siswa Kelas Iv B Sd Muhammadiyah 2 Kota Sorong. Qalam: Jurnal Ilmu Kependidikan, 5(2), 14-25. https://doi.org/10.33506/jq.v5i2.2 56

Basir, M. A., Hazira, K. V. A., \& Kusmaryono, I. (2020). Pengembangan Media Islamic Math Comics Dalam Meningkatkan Pemahaman 
Matematis dan Karakter Siswa. Journal of Chemical Information and Modeling, 9(3), 842-850.

Dyanto, F. H. (2014). Menerapkan Model Pembelajaran Kooperatif Untuk Meningkatkan Ketuntasan Belajar Siswa Dan Menanamkan Nilai-Nilai Pendidikan Karakter Di SMK Negeri 1 Sidoarjo. Jurnal Pendidikan Teknik Elektro, 3(3), 397-404.

Ekawati, T., Anggoro, B. S., \& Komarudin. (2019). Pengembangan Modul Pembelajaran Matematika Pada Materi Statistika Terintegrasi Nilai-Nilai Keislaman. AKSIOMA: Jurnal Program Studi Pendidikan Matematika, 8(1), 184-192. https://doi.org/10.24127/ajpm.v8i 1.1826

Fathurrahman, M. (2016). Meningkatkan Hasil Belajar Matematika Melalui Model Pembelajaran Cooperative Script Pada Siswa Sekolah Menengah Atas. Qalam: Jurnal Ilmu Kependidikan, 5(1), 1-7.

Handoko, H., \& Winarno, W. (2019). Pengembangan Perangkat Pembelajaran Matematika melalui Pendekatan Scaffolding Berbasis Karakter. Mosharafa: Jurnal ..., 8(3), 411-422. https://journal.institutpendidikan.a c.id/index.php/mosharafa/article/v iew/mv8n3_6

Heriyadi, H., \& Prahmana, R. C. I. (2020). Pengembangan Lembar Kegiatan Siswa Menggunakan Pendekatan Pendidikan Matematika Realistik. AKSIOMA: Jurnal Program Studi Pendidikan Matematika, 9(2), 395-412. https://doi.org/10.24127/ajpm.v9i 2.2782
Hidayah, N. (2018). Pengembangan Perangkat Pembelajaran Berbasis Subject Specific Pedagogy (SSP) Terintegrasi Pendidikan Karakter dan Revolusi Mental untuk SD/MI di Bandarlampung. $A R$ RIAYAH: Jurnal Pendidikan Dasar, 2(1), 51. https://doi.org/10.29240/jpd.v2i1. 461

Khoiriyah, U., \& Rizki, S. (2017). Pengembangan Bahan Ajar Himpunan Matematika Yang Dikaitkan Dengan Nilai-Nilai Islam. AKSIOMA: Jurnal Program Studi Pendidikan Matematika, 6(3), 315. https://doi.org/10.24127/ajpm.v6i 3.1142

Pratama, O. R., Lutfianto, M., \& Noviartati, K. (2019). Pengembangan Soal Matematika Mirip TIMSS Yang Memuat Nilai Karakter. Kreano, Jurnal Matematika Kreatif-Inovatif, 10(2), 179-185. https://doi.org/10.15294/kreano.v $10 \mathrm{i} 2.17970$

Setyo, A. A., \& Mulyono, M. (2019). Kombinasi Model Pembelajaran NHT dan Snowball Throwing Untuk Mengembangkan Ketrampilan Abad 21 Mahasiswa Universitas Muhammadiyah Sorong. Qalam: Jurnal Ilmu Kependidikan, 8(2), 82-91. https://doi.org/10.33506/jq.v8i2.7 00

Suprianto, Kholida, S. I., \& Andi, H. J. (2016). Pengaruh Pendekatan Contextual Teaching and Learning (CTL) Berbantuan Media Powerpoint Terhadap Peningkatan Hasil Belajar IPA Fisika. Buana Matematika: Jurnal Ilmiah Matematika dan Pendidikan Matematika, 2(2), 
DOI: https://doi.org/10.24127/ajpm.v10i1.3395

166-175.

https://doi.org/10.36456/buanamat ematika.v6i1:.377

Suprianto, T., Noer, S. H., \& Rosidin, U. (2020). Pengembangan Model Pembelajaran Group Investigation Berbantuan Soal Open Ended Untuk Meningkatkan Kemampuan Berpikir Reflektif Matematis. AKSIOMA: Jurnal Program Studi Pendidikan Matematika, 9(1), 72. https://doi.org/10.24127/ajpm.v9i 1.2583

Trisnawati, N F, \& Sundari, S. (2020). Efektifitas Model Problem Based Learning dan Model Group Investigation dalam Meningkatkan Karakter Anti Korupsi. Mosharafa: Jurnal, 9, 203-214.

https://journal.institutpendidikan.a c.id/index.php/mosharafa/article/v iew/mv9n2 03

Trisnawati, Nika Fetria. (2017). Efektivitas Model Pembelajaran Kooperatif Tipe Two Stay Two Stray Dengan Pendekatan Saintifik Dalam Pembelajaran Matematika Pada Siswa Smp Negeri 2 Kota Sorong. Median: Jurnal Ilmu Ilmu Eksakta, 9(3), 36. https://doi.org/10.33506/md.v9i3. 15
Trisnawati, Nika Fetria. (2019). Efektifitas Model Group Investigation Dalam Meningkatkan Hasil Belajar dan Self Efficacy. UNION: Jurnal Ilmiah Pendidikan Matematika, 7(3), 427. https://doi.org/10.30738/union.v7i 3.6126

Waluyo, E., Supiyati, S., \& Halqi, M. (2020). Mengembangkan Perangkat Pembelajaran Kalkulus Integral Berbasis Model Pengajuan dan Pemecahan Masalah untuk Meningkatkan Kemampuan Berpikir Kreatif Mahasiswa. Jurnal Elemen, 6(2), 357-366. https://doi.org/10.29408/jel.v6i2.2 334

Yuniati, S. (2018). Perangkat Pembelajaran Matematika Terintegrasi Karakter-Keislaman Melalui Pendekatan Kontekstual Di Propinsi Riau. MaPan, 6(1), 104-118. https://doi.org/10.24252/mapan.20 18v6n1a10 